\title{
ニッケル新生面の酸化初期における質量変化*1
}

\author{
田口正美 渡辺満生*2
}

秋田大学工学資源学部材料工学科

J. Japan Inst. Metals, Vol. 65, No. 1 (2001), pp. 38-44

(C) 2001 The Japan Institute of Metals

\section{Mass Change of Nickel Fresh Surface at the Beginning of Oxidation}

\begin{abstract}
Masami Taguchi and Maki Watanabe*2
Department of Materials Science and Engineering, Faculty of Engineering and Resource Science, Akita University, Akita 010-8502

There are many cases when atmospheric corrosion produces serious problems-for example, in electronic equipment. In this report, $\mathrm{Au}$ and $\mathrm{Ni}$ were vacuum-evaporated to produce a thin film on a quartz oscillator and the mass changes of the fresh surfaces during introduction/evacuation of $\mathrm{N}_{2}$ and artificial air were measured by the QCM technique in order to investigate the initial oxidation details of a fresh nickel surface near room temperature. The monolayer adsorption could be achieved on a fresh Au surface when the $\mathrm{N}_{2}$ pressure reached $1.01 \times 10^{5} \mathrm{~Pa}$, but the adsorbed layer was completely desorbed by evacuation of the gas. For the fresh Ni surface, the monolayer adsorption, which was formed within 10 seconds of the $\mathrm{N}_{2}$ introduction, did not disappear even if the $\mathrm{N}_{2}$ was evacuated. The mass change of the fresh Au surface during the introduction/evacuation of artificial air was substantially the same as that of $\mathrm{N}_{2}$. However, the XPS analysis revealed that a nickel compound, $\mathrm{NiO}$, was formed on the fresh $\mathrm{Ni}$ surface very early during the introduction of artificial air. A contaminant, $\mathrm{SO}_{2}$, had a tendency to accelerate the rate of mass gain during the gas introduction, while $\mathrm{H}_{2} \mathrm{O}$ only increased the mass of the initial adsorption layer.
\end{abstract}

(Received August 31, 2000; Accepted November 16, 2000)

Keywords: nickel, fresh surface, atmospheric corrosion, initial oxidation, QCM technique, mass change, adsorption, X-ray photoelectron spectroscopy

\section{1. 緒言}

電子機器には，マイクロメーター，時にはナノメーター オーダーの厚さの薄膜が使用されている．これらの薄膜で は, 通常の機械部品でそれほど問題とならない大気腐食が重 大な意味を持つ。つまり，一年で数マイクロメーターという 腐食速度は，機械部品では深刻なダメージにならないが，薄 膜を多用する電子機器では様々なトラブルを誘発する．電子 機器のメッキに使用される $\mathrm{Ni}$ 薄膜でも, 見かけ上腐食損傷 は認められないが，極表面では吸着や酸化が進行しており， 接合などの後処理を施した際に剥落などの製品不良を引き起 こす事例が多数報告されている.

室内環境に打ける $\mathrm{Ni}$ の腐食に関しては, Rice ら1)や Leygraf ら 2 ,3) などの研究があり, 腐食生成物として $\mathrm{Ni}(\mathrm{OH})_{2}, \mathrm{NiO}, \mathrm{NiCl}$ などが報告されている。しかし, 報告 の多くは数日から数ヶ月にわたる比較的長期間の腐食に関す るものであり, 生成直後の $\mathrm{Ni}$ 新生面について初期酸化挙動 を詳細に研究した例 ${ }^{4-7)}$ は極めて少ない。これは, 室温での 大気腐食による腐食損傷が軽微なため, 従来の計測法では対 応が困難なことに起因する，ところで，酸化などの界面反応 を研究する基本的な方法は反応に伴う質量変化を計測するこ

\footnotetext{
*1 1999年11月21日日本金属学会秋期大会において発表

*2 秋田大学大学院生, 現在 : 山形電子秼 (Graduate Student, Akita University, Present address: Yamagata Electronics Co. Ltd., Yamagata)
}

とであるが, 近年, 微少な質量変動を計測する方法として水 晶振動子マイクロバランス法(Quartz Crystal Microbalance Technique, 以後 QCM 法と記す)が開発され, 注目を集め ている ${ }^{8,9)}$. この方法は, 反応に伴う質量変動を水晶振動子 の振動数変化に置き換えて計測するもので, その検出感度は ナノグラムオーダーに達する．この值は通常のデジタル天秤 の検出感度の打よ々 10 万倍に相当することから，腐食速 度が極めて遅い室温近傍での大気腐食をその場測定すること が可能と期待される.

そこで, 本研究では, $\mathrm{QCM}$ 法を用いて生成直後の $\mathrm{Ni}$ 新 生面の初期酸化挙動を追究することにしたすなおち，オイ ルフリーの真空下で作製した $\mathrm{Au}$ ならびに $\mathrm{Ni}$ 新生面に対し, $298 \mathrm{~K}$ 一定で $\mathrm{N}_{2}$ の導入 · 排出を行い, 吸 · 脱着反応に伴う 質量変動をその場測定した. その後, $\mathrm{H}_{2} \mathrm{O}$ や微量污染ガス である $\mathrm{SO}_{2}$ を混入した $\mathrm{N}_{2}$ ならびに人工空気の導入・排出試 験を繰り返し, $\mathrm{Ni}$ 新生面の初期酸化挙動に及ぼす $\mathrm{O}_{2}, \mathrm{H}_{2} \mathrm{O}$ および $\mathrm{SO}_{2}$ の影響について検討を加えた.さらに，試験後 の金属新生面を $\mathrm{X}$ 線光電子分光により分析し, 腐食生成層 の化学結合状態を調査したので，報告する.

\section{2. 実 験 方 法}

\section{1 金属新生面の作製}

Fig. 1 には，実験装置の概略を示す。使用した水晶振動子 は基本振動数 $5 \mathrm{MHz}$ の AT カット水晶であり, 両面に電極 としてAuをコーティングしてある.これをマスセンサー 


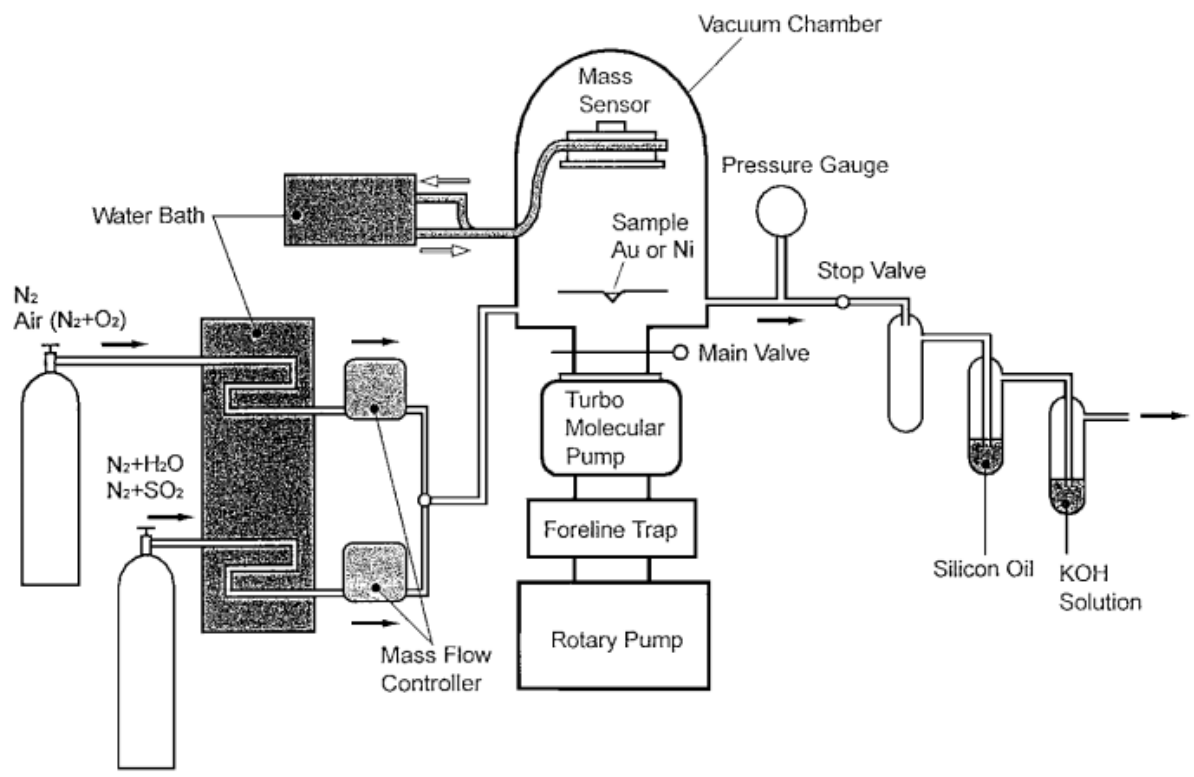

Fig. 1 Experimental apparatus.

(ULVAC, CRTS-4)に装着し，試料金属である Au 線（純度 99.95\%) あるいは $\mathrm{Ni}$ 線(純度 $99.9 \%$ ) を入れたタングステン ボートの直上に設置した。 その後, 真空チャンバー内を $1.33 \times 10^{-4} \mathrm{~Pa}$ 以下に排気し, タングステンボートに電流を 印加して試料金属を加熱蒸発せしめた. 真空排気システムに は, 磁気浮上型ターボ分子ポンプ(EDWARDS, EXT250)を 使用するとともに，そのバックアップを行うロータリーポン プとの間にフォアライントラップを設置した．そのため，真 空蒸着によって水晶振動子上に析出する金属新生面は, オイ ル污染の無い清浄なものと考えられる．この金属新生面につ いては，X 線回折（日本電子，JDX-3530)により結晶構造を 調査するとともに, 触針式表面粗さ計 (東京精密, サーフコ ム1400A)にて膜厚を測定した。

\section{2 試験ガスの導入・排出および振動数の計測}

$\mathrm{Au}$ あるいは $\mathrm{Ni}$ 新生面の初期酸化挙動を調査するため, $\mathrm{N}_{2}$ (純度 $99.9995 \%$ ) および人工空気 $\left(\mathrm{N}_{2}+21.0 \% \mathrm{O}_{2}\right.$, 純度 $99.9995 \%)$ 導入 · 排出試験を行った。 また, 水分や微量 污染物質の影響を検討するため, $\mathrm{N}_{2}$ や人工空気に $\left(\mathrm{N}_{2}+43.5\right.$ $\left.\mathrm{ppm} \mathrm{H}_{2} \mathrm{O}\right)$ あるいは $\left(\mathrm{N}_{2}+0.0488 \% \mathrm{SO}_{2}\right)$ ガスを混入した試験 を実施した。すなわち，真空蒸着にて金属新生面を生成させ た直後, 排気システムのメインバルブを閉め, マスフローコ ントローラ(エステック, SEC-400MARK3) にて流速 $8.3 \times$ $10^{-6} \mathrm{~m}^{3} \mathrm{~s}^{-1}$ で試験ガスを導入した。 ガス導入によって, 計 測室でもある真空チャンバー内の圧力は次第に上昇し, 約 3 $\mathrm{ks}$ で大気圧 $1.01 \times 10^{5} \mathrm{~Pa}$ に到達する. 本研究では，この時 点で付属のストップバルブを開放し, 試験ガスを大気中に放 出した。その後，ガス排出に伴う金属新生面の質量変化を調 査するため, $7.2 \mathrm{ks}$ で再度真空排気を行った. ガス導入・排 出過程での金属新生面の質量変化は, 水晶振動子の振動数変 化として周波数カウンタ（日置電気，3601）を通じてパーソ ナルコンピュータに記録された。なお，反応温度を一定にす るため, 試験ガスの流路には $298 \mathrm{~K}$ に制御した恒温水槽を
設けるとともに，マスセンサーの外周にもこの恒温水を循環 させた。

\section{$2.3 \mathrm{X}$ 線光電子分光}

試験ガス導入後の金属新生面の化学結合状態を調査するた めに, XPS (日本電子, JPS-9000SX)による分析を行った. $\mathrm{X}$ 線ターゲットには $\mathrm{Mg}$ を使用し，加速電圧は $10 \mathrm{kV}$ ，エミ ッション電流は $20 \mathrm{~mA}$ に設定した．分析では，エッチング を行わずに光電子スペクトルを収集した後, Ar ガス圧 $5 \times$ $10^{-2} \mathrm{~Pa}$, 加速電圧 $500 \mathrm{~V}$, エミッション電流 $6.4 \mathrm{~mA}$ の条件 でArイオンエッチングを繰り返し，スペクトルを収集した。

\section{3. 結 果 と考察}

\section{1 水晶振動子の質量検出感度}

水晶振動子における質量変化 $d m\left(\mathrm{~kg} \mathrm{~m}^{-2}\right)$ と振動数変化 $d f(\mathrm{~Hz})$ との間には，Sauerbreyの式10)と呼ばれる式 (1)が 成立する。

$$
d m / d f=-N \rho_{\mathrm{q}} / f_{0}^{2}
$$

ここで， $f_{0}$ は基本振動数 $(\mathrm{Hz}), N$ は振動数定数 $(\mathrm{Hz} \mathrm{m}), \rho_{\mathrm{q}}$ は水晶の密度 $\left(2.65 \times 10^{-3} \mathrm{~kg} \mathrm{~m}^{-3}\right)$ である. 本研究では, 基 本振動数 $f_{0}=5 \times 10^{6}(\mathrm{~Hz})$, 振動数定数 $N=1.67 \times 10^{3}(\mathrm{~Hz} \mathrm{~m})$ の AT カット水晶振動子を使用しているので，式 (1)は式 ( 2 ) となる.

$$
d m=-1.77 \times 10^{-7} d f
$$

い屯, 水晶振動子上に密度 $\rho_{\mathrm{Ni}}\left(8.85 \times 10^{-3} \mathrm{~kg} \mathrm{~m}^{-3}\right)$, 膜厚 $l$ $(\mathrm{nm})$ の $\mathrm{Ni}$ 薄膜を蒸着すると, 式 $(3)$ で示される質量変化 $d m\left(\mathrm{~kg} \mathrm{~m}^{-2}\right)$ を生じる.

$$
d m=\rho_{\mathrm{Ni}}\left(l \times 10^{-9}\right)
$$

したがって, 式(3)を式(2)に代入すると，式(4)が導き 出される.

$$
d f=-50.0 l
$$

Fig. 2 は, 水晶振動子上に膜厚の異なる 9 種類の $\mathrm{Ni}$ 薄膜 
を蒸着し，質量検出感度を検証した結果である・ $\mathrm{Ni}$ 薄膜の 膜厚 $l$ が増大するに従い, 水晶振動子の振動数 $f$ は一次関数 的に低下した．その結果，振動数変化 $d f$ と膜厚 $l$ に関する 測定データは, 図中直線で表した式 $(4)$ に沿うことが判明 した.よって，水晶振動子に打ける質量変化 $d m$ は，計測さ れる振動数変化 $d f$ から式 $(2)$ に基づいて正確に算出できる と言える。

\section{$3.2 \mathrm{Au}$ および $\mathrm{Ni}$ 新生面における $\mathrm{N}_{2}$ の吸着挙動}

真空蒸着により作製した $\mathrm{Au}$ ならびに $\mathrm{Ni}$ 新生面の XRD パターンを Fig. 3 に示す. Au 新生面では, $2 \theta=38^{\circ}$ 付近に (111)面からの強い回折ピークが認められる.一方, $\mathrm{Ni}$ 新生 面の XRD パターンでは， $2 \theta=45$ 付近に唯一明確なピーク を観察できる。これは $\mathrm{Ni} の(111)$ 面からの回折線と一致す ることから，両新生面とも(111)面に結晶配向していること が伺える.なお, $\mathrm{Ni}$ 新生面の $27^{\circ}$ 付近に見られるブロードなピ

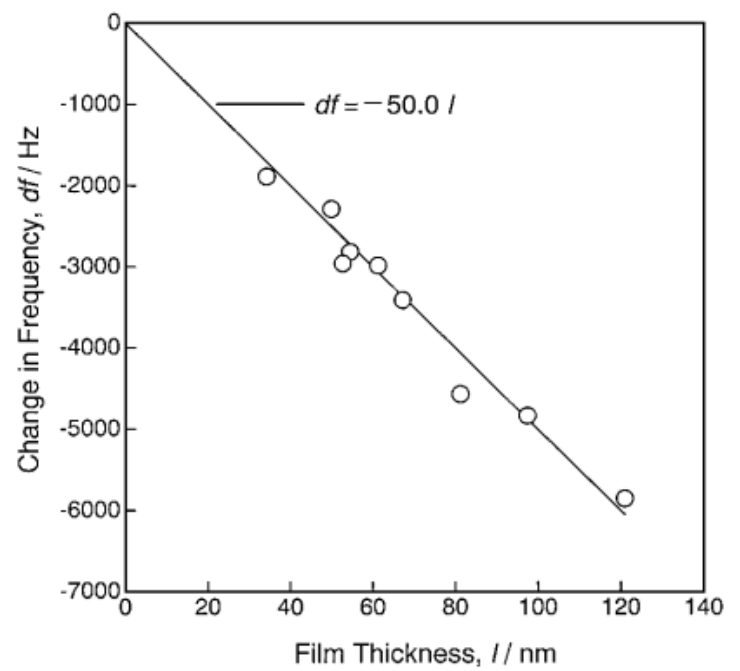

Fig. 2 Relationship between change in frequency of quartz oscillator and thickness of vacuum-evaporated $\mathrm{Ni}$ film.
一クは，下地の非晶質ガラスの情報が加算された結果である.

Fig. 4 は， $\mathrm{N}_{2}$ ならびに人工空気導入・排出に伴う $\mathrm{Au}$ お よび $\mathrm{Ni}$ 新生面での質量変化を示す。横軸の原点はガス導入 開始点であるが，作業の手順上，真空蒸着による新生面作製 から約 $6 \mathrm{~s}$ が経過している. ガスは $8.3 \times 10^{-6} \mathrm{~m}^{3} \mathrm{~s}^{-1}$ 一定で 導入されており, 計測室内の圧力は連続的に上昇する. ガス 圧は約 $3 \mathrm{ks}$ で大気圧 $1.01 \times 10^{5} \mathrm{~Pa}$ に達し，その後は $7.2 \mathrm{ks}$ まで一定である。 また， $7.2 \mathrm{ks}$ ではバルブを閉じ，計測室内

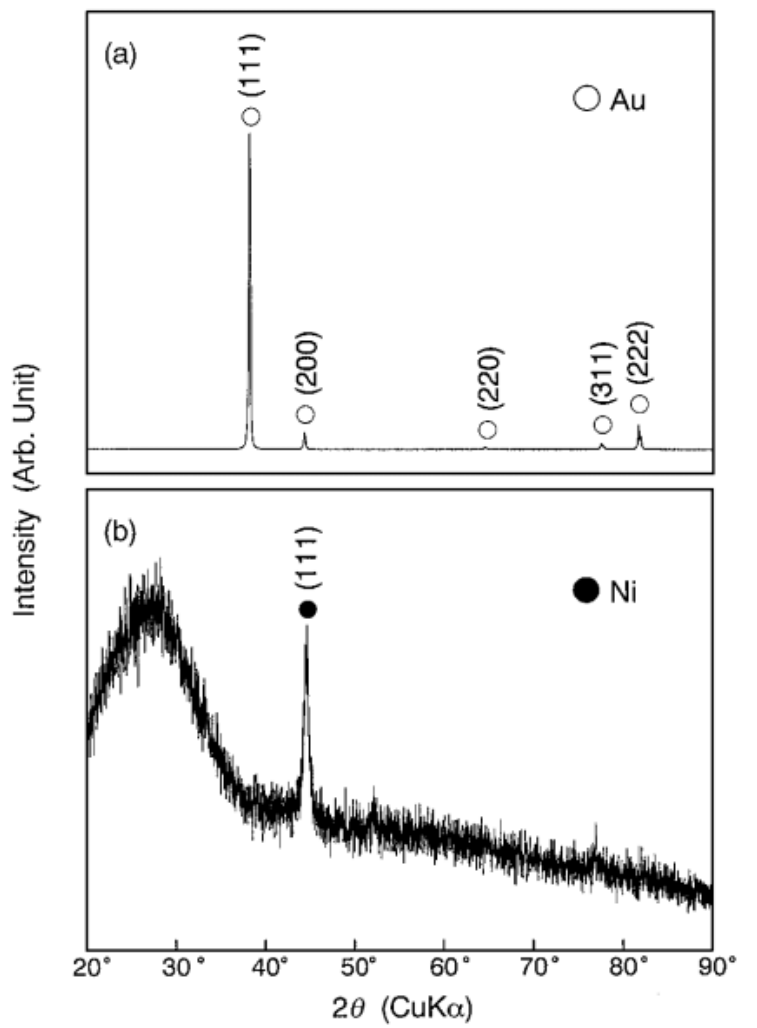

Fig. 3 X-ray diffraction patterns of fresh (a) Au and (b) Ni surfaces produced by vacuum evaporation.
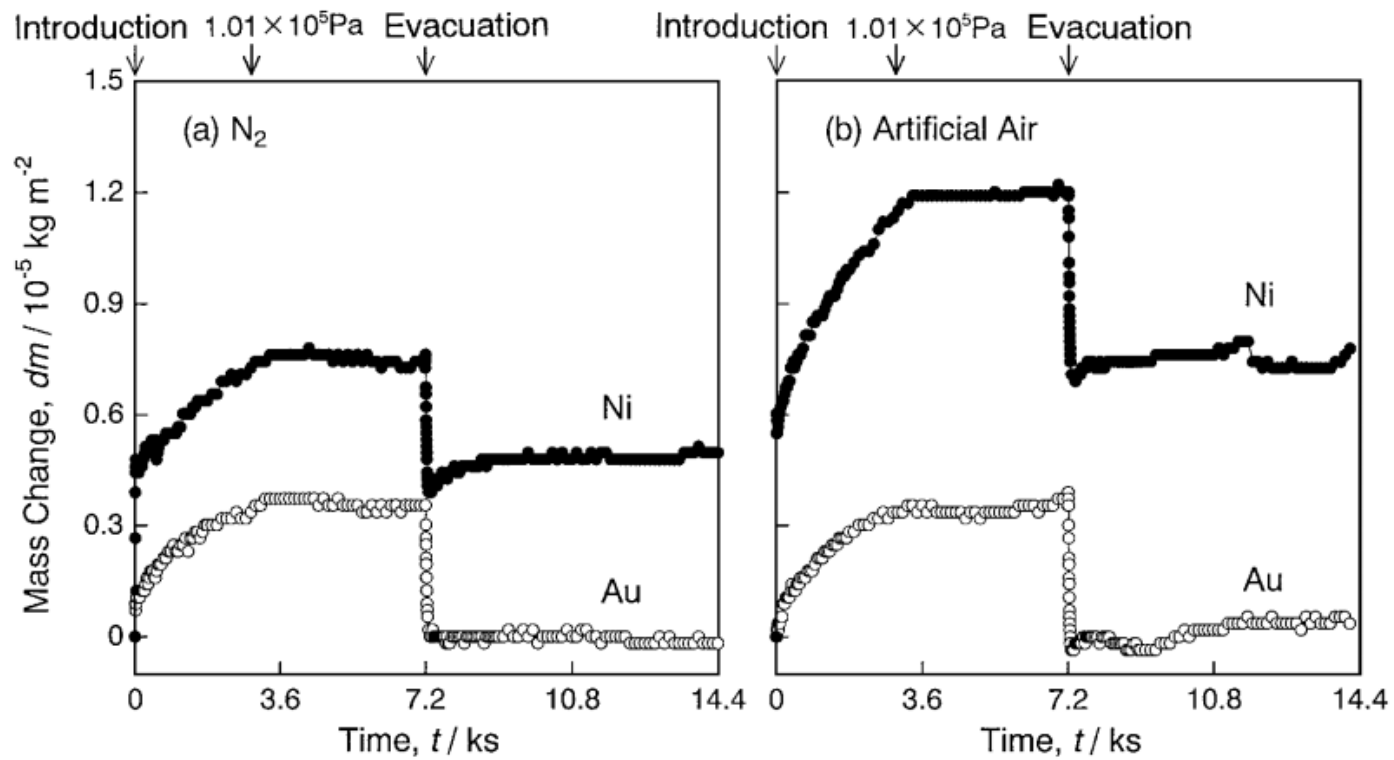

Fig. 4 Mass changes of fresh Au and Ni surfaces during introduction/evacuation of (a) $\mathrm{N}_{2}$ and (b) artificial air. 
を真空排気することから，ガス圧は急激に低下している. (a)の $\mathrm{N}_{2}$ 導入において, $\mathrm{Au}$ 新生面での質量はガス圧の上昇 とともに徐々に増加し, 約 $3 \mathrm{ks}$ でガス圧が大気圧に達した 時点では $0.36 \times 10^{-5} \mathrm{~kg} \mathrm{~m}^{-2}$ となった. その後, ガス圧が $1.01 \times 10^{5} \mathrm{~Pa}$ 一定の下では, 質量も一定值を保った. ところ が， $7.2 \mathrm{ks}$ において $\mathrm{N}_{2}$ の排出を行うと, 質量は $60 \mathrm{~s}$ 程度で ガス導入前の值まで急激に低下した。一方， $\mathrm{Ni}$ 新生面では, $\mathrm{Au}$ 新生面と異なり， $\mathrm{N}_{2}$ 導入 $10 \mathrm{~s}$ 以内のごく初期に $0.4 \times$ $10^{-5} \mathrm{~kg} \mathrm{~m}^{-2}$ 以上の急激な質量増加が認められた. しかし, その後は $\mathrm{Au}$ 新生面の場合と同様, ガス圧の上昇とともに質 量は徐々に増加し, 約 $3 \mathrm{ks}$ でガス圧が大気圧に達した後は

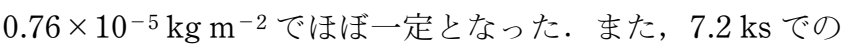
ガス排出により質量増加量は $0.4 \times 10^{-5} \mathrm{~kg} \mathrm{~m}^{-2}$ 程度まで低 下するが, $\mathrm{Au}$ 新生面の場合とは異なり, 質量はガス導入前 の状態には戻らないことが示された。したがって， $\mathrm{N}_{2}$ 導 入・排出による質量変動は, $\mathrm{Au}$ 新生面では可逆的であるが, $\mathrm{Ni}$ 新生面では不可逆であり， $\mathrm{N}_{2}$ 排出後も吸着層が残存する と結論できる。

温度一定でガス圧を上昇させると, 固体表面の吸着量は増 加する。その際の吸着等温式としては，Langmuir 式あるい は BET 式が想定される. 前者は吸着が単層に限定される場 合に適用でき，次式で示される.

$$
v=v_{\mathrm{m}} K P /(1+K P)
$$

ここで, $v$ は吸着量 $\left(\mathrm{kg} \mathrm{m}^{-2}\right), v_{\mathrm{m}}$ は表面を全て吸着種で覆 うのに必要な吸着量 $\left(\mathrm{kg} \mathrm{m}^{-2}\right), P$ は気体の圧力 $(\mathrm{Pa}), K$ は吸 着平衡定数である. 本研究では, 計測室内のガス圧 $P$ は, 約 $3 \mathrm{ks}$ まで導入時間 $t$ とともに連続的に上昇する。この 際, 吸着速度が極めて速く, 各ガス圧に打いて平衡が達成さ れたと仮定する。 さらに，吸着量 $v$ として QCM 法で計測し た質量増加量 $d m$ を， $v_{\mathrm{m}}$ として $d m_{\mathrm{m}}$ を用いると，式(5)は 式( 6 )のように変形できる.

$$
P / d m=1 /\left(d m_{\mathrm{m}} K\right)+P / d m_{\mathrm{m}}
$$

Fig. 5 には， $298 \mathrm{~K}$ における $\mathrm{Au}$ 新生面上での $\mathrm{N}_{2}$ の吸着 等温線を示す。これは式 $(6)$ に基づいた「Langmuir 型吸着」 判定プロットに他ならず， $P<1.3 \times 10^{4}(\mathrm{~Pa})$ の低圧領域を除 けば，データに直線性が見いだせる. また，同様の手順で多 層吸着に適用される BET 式に関する解析も行ったが, 解析 データからは吸着が「BET 型吸着」で進行するとの結論は 得られなかった。 そのため, $\mathrm{Au}$ 新生面への $\mathrm{N}_{2}$ の導入では, Langmuir 型吸着すなわち単層吸着が進行すると推察した.

Table 1 には, $\mathrm{N}_{2}$ の導入・排出に伴う $\mathrm{Au}$ および $\mathrm{Ni}$ 新生 面の質量変化を示す． $\mathrm{Au}$ 新生面では， $\mathrm{N}_{2}$ の導入直後におい て $\mathrm{Ni}$ 新生面で見られるような急激な質量増加は無く，ガス 圧の上昇とともに質量は徐々に増加する．3〜 $7.2 \mathrm{ks}$ では $1.01 \times 10^{5} \mathrm{~Pa}$ における平衡吸着層が得られるが，その際の質 量増加量の平均値は $3.54 \times 10^{-6} \mathrm{~kg} \mathrm{~m}^{-2}$ と計算できる．この 吸着層は前述のように単層と推察できるが， $7.2 \mathrm{ks} に$ に掞りる 真空排気によって $\mathrm{Au}$ 新生面から完全に脱着した。それゆ え, この吸着種はファンデルワールスカのような弱い力で $\mathrm{Au}$ 新生面上に物理吸着していたと考察できる. そこで，こ の単層吸着の質量データに基づき, $\mathrm{Ni}$ 新生面上に形成され る吸着層数を計算した，その結果， $\mathrm{Ni}$ 新生面では， $\mathrm{N}_{2}$ 導入

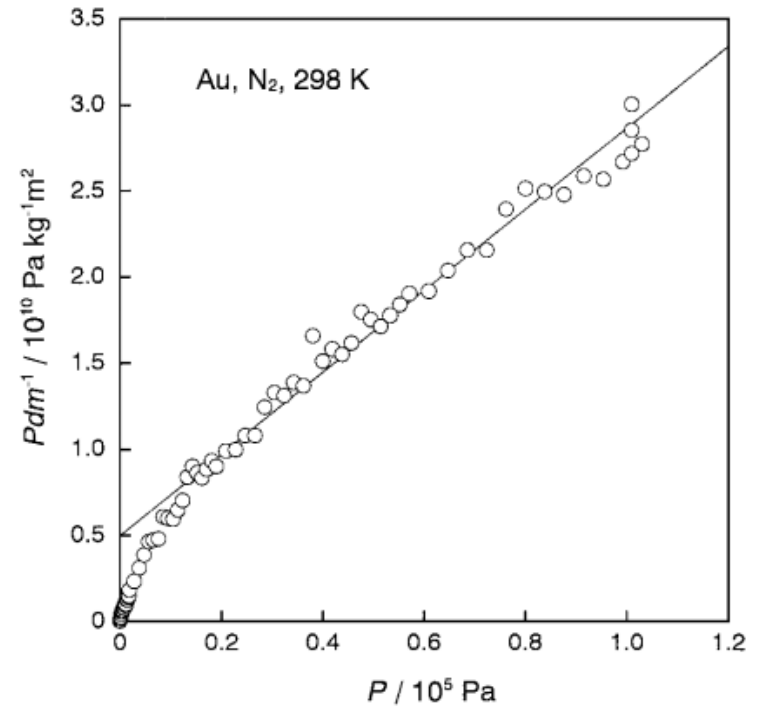

Fig. 5 The Langmuir adsorption isotherm of $\mathrm{N}_{2}$ on fresh $\mathrm{Au}$ surface at $298 \mathrm{~K}$

Table 1 Mass gains of fresh $\mathrm{Au}$ and $\mathrm{Ni}$ surfaces during introduction/evacuation of $\mathrm{N}_{2}$.

\begin{tabular}{cccccc}
\hline \multirow{2}{*}{$\begin{array}{c}\text { Fresh } \\
\text { surface }\end{array}$} & \multicolumn{4}{c}{ Mass gain $\left(10^{-6} \mathrm{~kg} \mathrm{~m}^{-2}\right)$} \\
\cline { 2 - 3 } \cline { 5 - 6 } & $10 \mathrm{~s}$ & $3 \sim 7.2 \mathrm{ks}$ & & \multicolumn{2}{c}{ Gas evacuation } \\
\cline { 2 - 3 } $\mathrm{Au}$ & - & 3.54 & & 0 & $14.4 \mathrm{ks}$ \\
$\mathrm{Ni}$ & 3.89 & 7.61 & & 3.89 & 0 \\
\hline
\end{tabular}

Table 2 Change in number of absorption layers on fresh $\mathrm{Au}$ and $\mathrm{Ni}$ surfaces during introduction/evacuation of $\mathrm{N}_{2}$.

\begin{tabular}{cccccc}
\hline \multirow{2}{*}{$\begin{array}{c}\text { Fresh } \\
\text { surface }\end{array}$} & \multicolumn{4}{c}{ Number of absorption layers } \\
\cline { 2 - 3 } & $10 \mathrm{~s}$ & $3 \sim 7.2 \mathrm{ks}$ & & \multicolumn{2}{c}{ Gas evacuation } \\
\cline { 2 - 3 } \cline { 4 - 6 } $\mathrm{Au}$ & - & $(1.00)$ & & 0 & $14.4 \mathrm{ks}$ \\
$\mathrm{Ni}$ & 1.10 & 2.15 & & 1.10 & 0 \\
\hline
\end{tabular}

$10 \mathrm{~s}$ 以内のごく初期に単層(1.10層)を生成することが分かっ た。これは， $\mathrm{Ni}$ 新生面と吸着種の親和力が $\mathrm{Au}$ 新生面のそ れに比較して強いことに起因する。その後, $\mathrm{N}_{2}$ ガス圧の上 昇に伴い初期生成の単層上に沶いてらに吸着が進行するが, $\mathrm{N}_{2}$ ガス圧が $1.01 \times 10^{5} \mathrm{~Pa}$ に達した時点で吸着層はそれ以上 増大せず, 平均2.15層に留まる. しかも, 真空排気を行うと, $60 \mathrm{~s}$ 以内に上部に存在した第 2 層は全て取り除かれ，単層 (1.10層)に戻ることが判明した(Table 2 参照).

Fig. 6 は $\mathrm{Au}$ 抢よび $\mathrm{Ni}$ 新生面の $\mathrm{N} 1 \mathrm{~s}$ X 線光電子スペクト ルである. $\mathrm{Au}$ 新生面ではピークは全く観測されない。この 事は, $\mathrm{N}_{2}$ 導入・排出試験に打いてガスは表面に吸着する が，その吸着力は極めて弱く，真空排気で容易に脱着するこ とに関連する。これに対し， $\mathrm{Ni}$ 新生面では $\mathrm{Ar}$ イオンエッチ ング 30 おび $60 \mathrm{~s}$ において $398 \mathrm{eV}$ 付近にブロードなピーク を観測できる。この值は Swartz ら ${ }^{11)}$ が $\mathrm{Ni}$ 上の $\mathrm{N}_{2}$ 分子の結 合エネルギーとして報告している $399 \mathrm{eV} よ り も ~ 1 \mathrm{eV}$ 程度 低い。また，Arイオンエッチングを施さない場合には， 


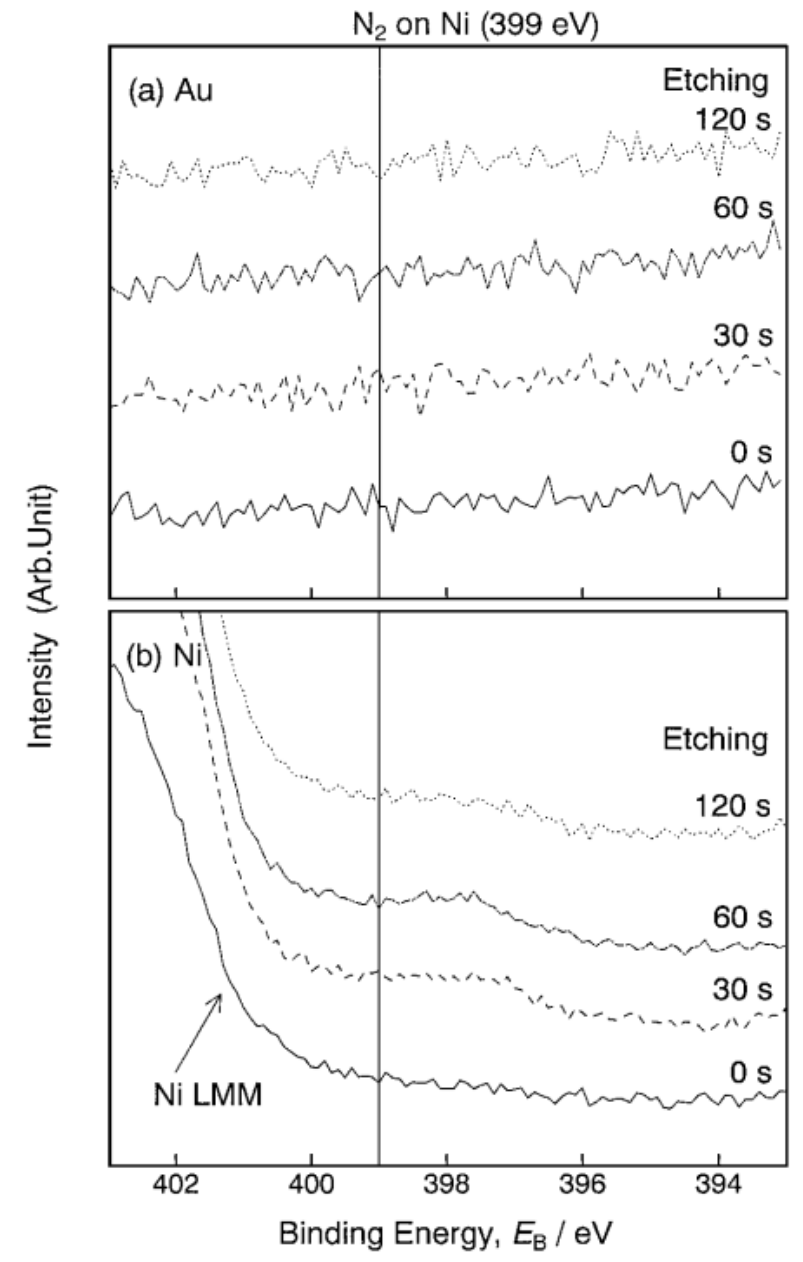

Fig. 6 N1s spectra of fresh (a) Au and (b) Ni surfaces after introduction/evacuation of $\mathrm{N}_{2}$.

ピークは見出せないが，それは試料をXPS に取り付ける際 いったん大気中に暴露する必要があり, 表層が空気中の $\mathrm{O}_{2}$ や $\mathrm{H}_{2} \mathrm{O}$ 等によって覆われたためと解釈できる.したがって, Ar イオンエッチング 30 抢よ゙ $60 \mathrm{~s}$ で認められるブロードな ピークは, $\mathrm{N}_{2}$ 導入・排出試験で $\mathrm{Ni}$ 新生面上に吸着した化学 種を示す重要な証拠と考えられる.

\section{$3.3 \mathrm{Ni}$ 新生面の初期酸化に及ぼす $\mathrm{O}_{2}, \mathrm{H}_{2} \mathrm{O}$ および $\mathrm{SO}_{2}$ の 影響}

次いで, $\mathrm{Ni}$ 新生面の初期酸化挙動に及ぼす $\mathrm{O}_{2}$ の影響を調 査するため, $\mathrm{N}_{2}$ に代えて人工空気の導入・排出試験を実施 した(Fig. 4 (b)参照). Au 新生面での人工空気導入・排出に 伴う質量変化は， $\mathrm{N}_{2}$ 導入・排出の場合とほとんど変わらな い.したがって, Au 新生面では, 人工空気導入・排出にお いても単層での吸・脱着反応が進行すると推定できた. 一方, $\mathrm{Ni}$ 新生面では, 人工空気導入に扔いても $\mathrm{N}_{2}$ の場合と同様ご く初期に急激な質量増加が認められ，その量は人工空気の方 が大きい。また，その後の質量増加も人工空気の方が著し く，ガス圧が $1.01 \times 10^{5} \mathrm{~Pa}$ に達した時点での值は $\mathrm{N}_{2}$ の 1.5 倍になった．さらに， $7.2 \mathrm{ks}$ でのガス排出に伴う質量減少を 見ると， $\mathrm{N}_{2}$ より人工空気の方が著しいが，残存する吸着層 は人工空気の方が大きいことが分かる。ここで，Au 新生面

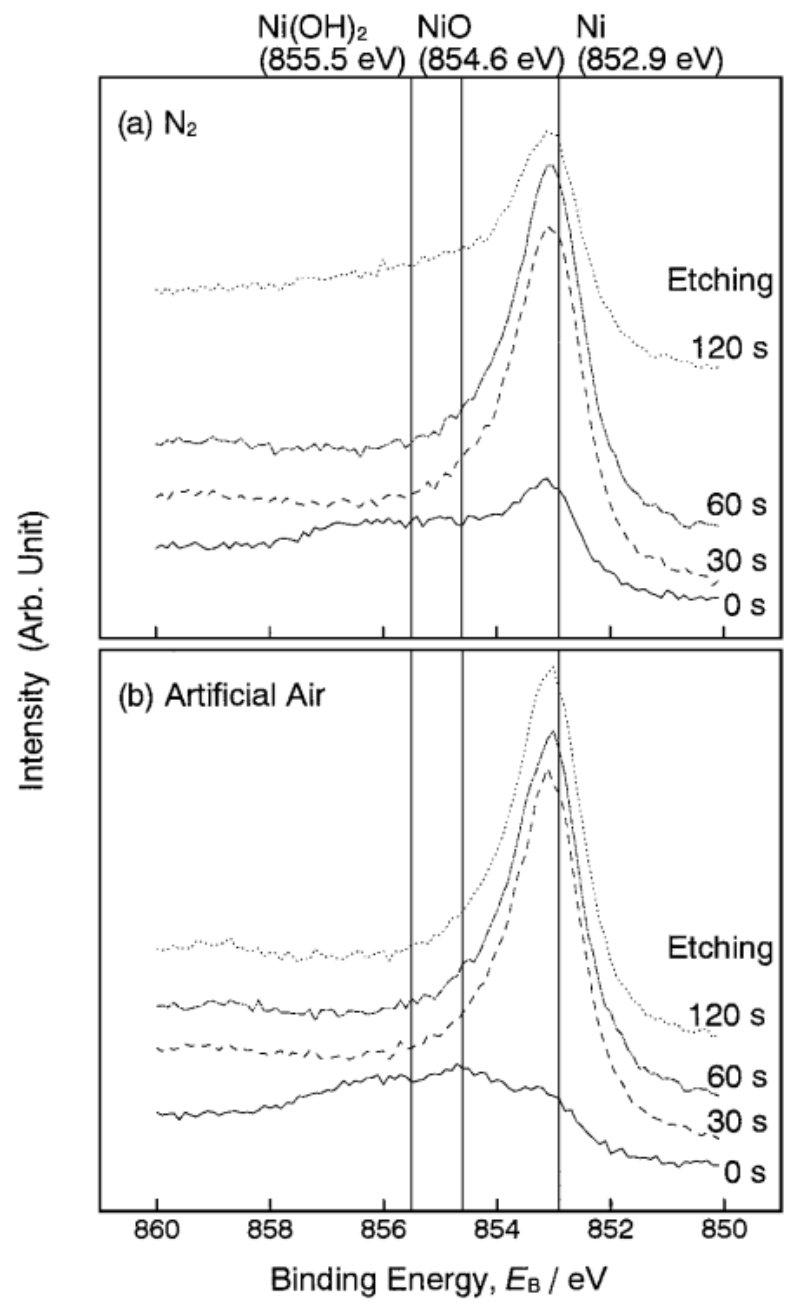

Fig. $7 \mathrm{Ni2p}$ spectra of fresh $\mathrm{Ni}$ surfaces after introduction/ evacuation of (a) $\mathrm{N}_{2}$ and (b) artificial air.

上の吸着層を単層と見なして計算を行うと, 残存吸着層は約 2.1層となった。

Fig. 7 には, $\mathrm{N}_{2}$ ならびに人工空気導入・排出後の $\mathrm{Ni}$ 新生 面の Ni2p X 線光電子スペクトルを示す. Ar イオンエッチ ングを施さない場合, $\mathrm{N}_{2}$ 導入・排出後の $\mathrm{Ni}$ 新生面では, $852.9 \mathrm{eV}$ 付近の金属 $\left.\mathrm{Ni}^{12}\right)$ 打よび $855.5 \mathrm{eV}$ の $\mathrm{Ni}(\mathrm{OH})_{2}{ }^{13,14)}$ に関係すると推察できるブロードなピークが認められる，と ころが，人工空気の場合には， $852.9 \mathrm{eV}$ 付近のピークは大 幅に減衰し, 代わって $854.2 \mathrm{eV}$ 付近に, $\mathrm{N}_{2}$ 導入 ·排出の試 料には見られないピークが観測できた。このピークは $\mathrm{NiO}$ の結合エネルギー $854.2 \mathrm{eV}^{2,15}$ に一致することから, 導入ガ スに $\mathrm{O}_{2}$ が混在する場合, 初期段階において $\mathrm{Ni}$ 新生面上に $\mathrm{NiO}^{16)}$ が生成する可能性を指摘できる.さらに, Fig. 8 に は，その $01 \mathrm{~s} \mathrm{X}$ 線光電子スペクトルを示す。両ガスでは, $\mathrm{Ar}$ エッチングを施さない場合のスペクトルに大きな違いが 認められる.すなわち, $\mathrm{N}_{2}$ 導入で認められる $530 \mathrm{eV}$ 付近の ピークが，人工空気導入に扔いて著しく増大している。この ピークエネルギーは $\mathrm{NiO}$ に関する文献值 $529.3 \mathrm{eV}^{15)}$ とは一 致しないが，著者らが高純度酸化物を用いて調査した値 $530.0 \mathrm{eV}^{177}$ にほぼ一致した. そのため, 前述の $\mathrm{Ni} 2 \mathrm{p} \mathrm{X}$ 線光 電子スペクトルの知見と併せて, 人工空気を導入した $\mathrm{Ni}$ 新 
生面においては極表層に化合物 $\mathrm{NiO}$ が生成すると結論でき る.なお， $531.5 \mathrm{eV}$ に認められるピークは，Ar イオンエッ チングにより容易に消失することから，XPSへの試料取り

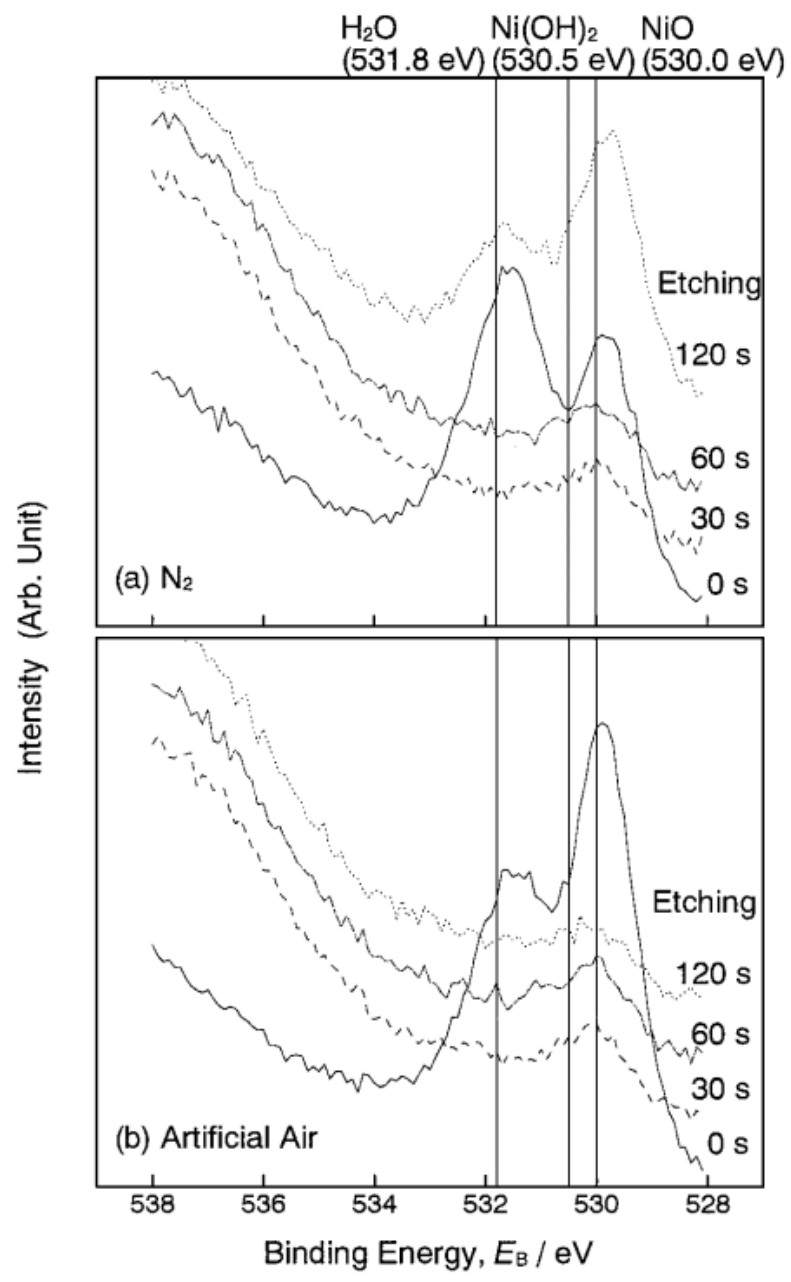

Fig. 8 O1s spectra of fresh $\mathrm{Ni}$ surfaces after introduction/ evacuation of (a) $\mathrm{N}_{2}$ and (b) artificial air.
付けの際に大気から吸着した $\mathrm{H}_{2} \mathrm{O}$ と判断される.

Fig. 9 には, $\mathrm{N}_{2}$ あるいは人工空気導入・排出に伴う $\mathrm{Ni}$ 新 生面の質量変化に及ぼす $\mathrm{H}_{2} \mathrm{O}$ ならびに $\mathrm{SO}_{2}$ 混入の影響を示 す. $\mathrm{H}_{2} \mathrm{O}$ を $43.5 \mathrm{ppm}$ 混入したガスと未混入のそれを比較す ると, $\mathrm{N}_{2}$ および人工空気の両方において, $\mathrm{H}_{2} \mathrm{O}$ が導入 $10 \mathrm{~s}$ 以内での質量増加やガス排出後の残存量を増加させることが 分かる.しかしながら，ガス圧 $1.01 \times 10^{5} \mathrm{~Pa}$ に打ける質量 変動にはほとんど違いが認められない，そのため，ガス導入 の初期段階では $\mathrm{H}_{2} \mathrm{O}$ は単に吸着量を増大させるにすぎない と判断される.ところが，污染ガスである $\mathrm{SO}_{2}$ を $10 \mathrm{ppm}$ 混 入した場合には， $\mathrm{N}_{2}$ 抢よび人工空気の両方に拈いて，10 $\mathrm{s}$ 〜約 $3 \mathrm{ks}$ の質量増加の勾配が急峻になることが示された. さらに，ガス圧が $1.01 \times 10^{5} \mathrm{~Pa}$ に保持された約 $3 \sim 7.2 \mathrm{ks}$ に おいても，質量が引き続き増加することが判明した.

$\mathrm{N}_{2}$ ならびに人工空気導入・排出における質量変動より $\mathrm{Ni}$ 新生面の初期酸化挙動を解釈すると, 次のようになる。ガス 導入 $10 \mathrm{~s}$ のごく初期にできる吸着層は， $\mathrm{N}_{2}$ では 1.1 層であ るが，人工空気では 1.7 層程度になる。これは $\mathrm{Ni}$ と $\mathrm{O}$ の親 和力が $\mathrm{Ni}$ と $\mathrm{N}$ のれれりも強く, XPS 分析が示すよう に，一部に化合物 $\mathrm{NiO}$ が生成することに起因すると考えら れる. ガス導入を続けると約 $3 \mathrm{ks}$ でガス圧は $1.01 \times 10^{5} \mathrm{~Pa}$ に達するが，その際の吸着層数は $\mathrm{N}_{2}$ 導入で約 2.2 なのに対 し，人工空気では 3.4 程度まで増大する. また， $7.2 \mathrm{ks} に お$ けるガス排出では， $\mathrm{N}_{2}$ 導入における上部吸着層はほぼ消失 し, 吸着層数は 1.1 程度まで減少するが，人工空気では 2.0 層 ほど残存する。これは，化合物 $\mathrm{NiO}$ とその上部に吸着した ガス種の結合力が比較的強いことを示唆する。をた， $\mathrm{H}_{2} \mathrm{O}$ や微量污染ガスである $\mathrm{SO}_{2}$ と化合物 $\mathrm{NiO}$ の結合力はさらに 強力であり, $\mathrm{Ni}$ 新生面の初期酸化の進行に重要な役割を果 たすと推察できる。ただ，混在する $\mathrm{H}_{2} \mathrm{O}$ は初期吸着層や残 存する吸着層の質量を増やすが，単独ではこの段階でそれ以 上の影響は無いと思われる。それに対し，污染物質である $\mathrm{SO}_{2}$ の存在は吸着層を増大させる効果を持つ、つまり，ガス
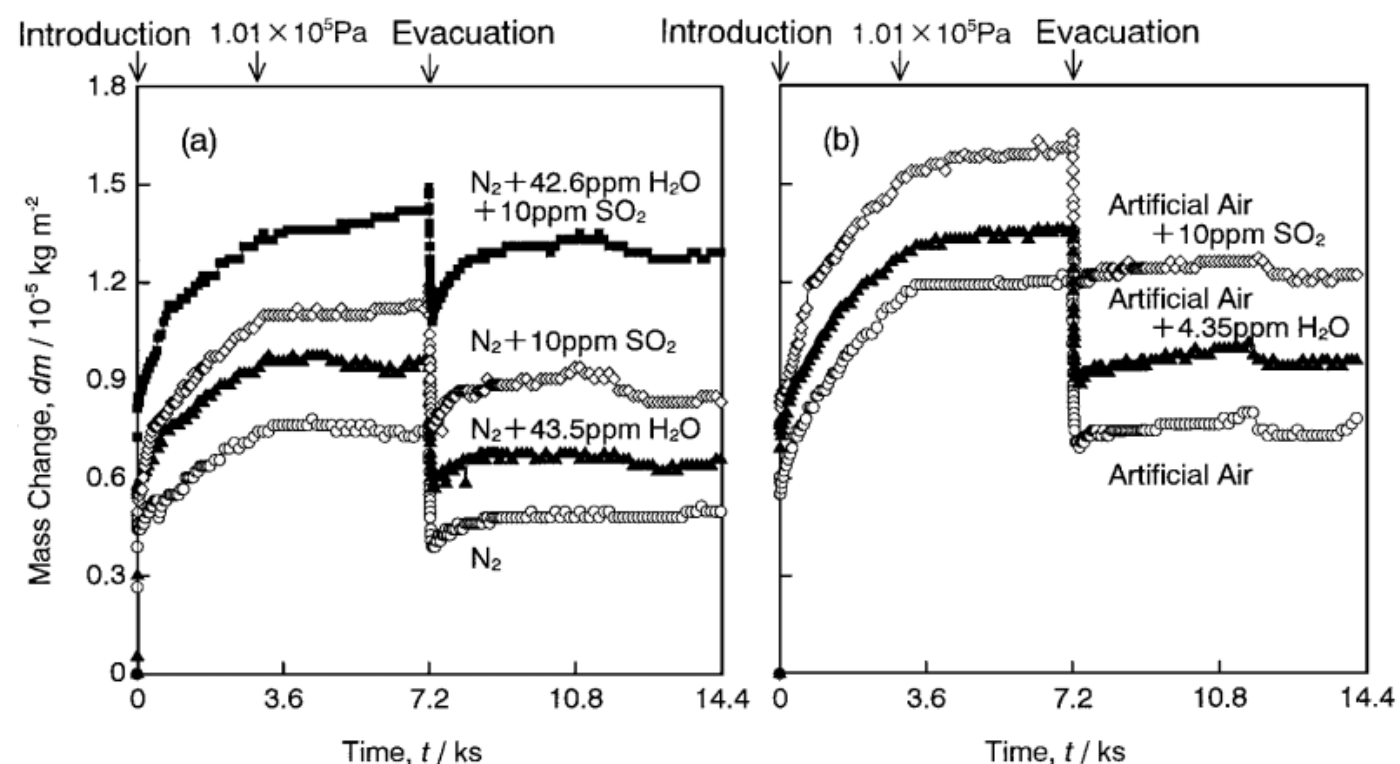

Fig. 9 Mass changes of fresh Ni surfaces during introduction/evacuation of (a) $\mathrm{N}_{2}$ and (b) artificial air containing $\mathrm{H}_{2} \mathrm{O}$ and $/$ or $\mathrm{SO}_{2}$. 


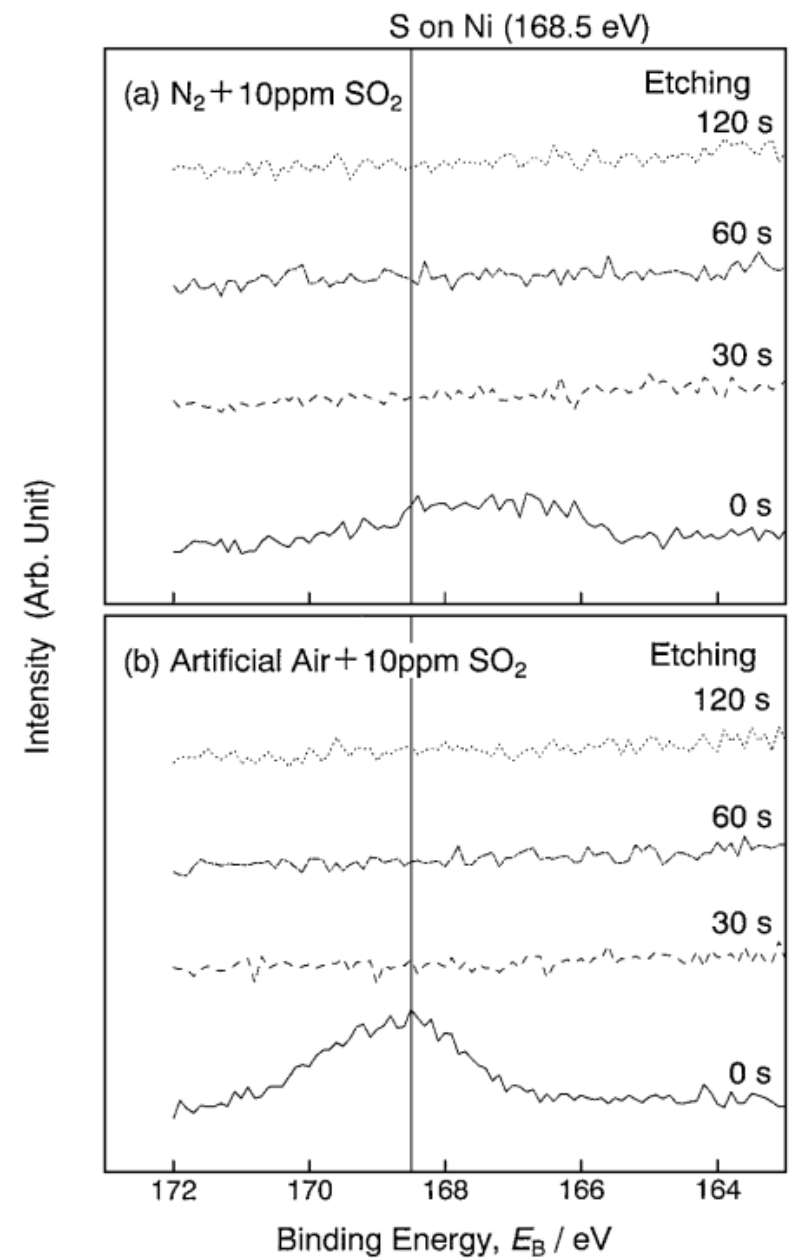

Fig. 10 S2p spectra of fresh Ni surfaces after introduction/ evacuation of (a) $\mathrm{N}_{2}$ and (b) artificial air containing $10 \mathrm{ppm}$ $\mathrm{SO}_{2}$

圧上昇時の質量増加の勾配を急峻化させるとともに，平衡力゙ 又圧 $1.01 \times 10^{5} \mathrm{~Pa}$ に打ける質量を漸次増大させる． $\mathrm{SO}_{2}$ を 混入させた $\mathrm{N}_{2}$ および人工空気導入・排出後の $\mathrm{Ni}$ 新生面の $\mathrm{S} 2 \mathrm{p}$ スペクトルでは, Ar イオンエッチング無しの状態での みピークが認められた (Fig. 10 参照). 長期間の $\mathrm{SO}_{2}$ 混入ガ スによる室内酸化では，一般にニッケル $($ II) 硫化物が生成す るとされる3 .しかし，(a) $\mathrm{N}_{2}+10 \mathrm{ppm} \mathrm{SO}$ 導入の際の結合 エネルギー $167 \sim 168 \mathrm{eV}$ や (b) 人工空気 $+10 \mathrm{ppm} \mathrm{SO}_{2}$ 導入 の結合エネルギー $168.5 \mathrm{eV}$ は, 報告されている $\mathrm{NiS}$ の結合 エネルギー $162.8 \mathrm{eV}^{18)}$ と大きく異なる．むしろ， $\mathrm{SO}_{2}$ の結 合エネルギー $(168 \mathrm{eV} \text { 前後 })^{19)}$ に近い。これらの事柄は, $\mathrm{SO}_{2}$ がその結合状態を大きく変えず，ごく初期に生成する化 合物層よりもその後に生成する上部吸着層に濃縮することを 意味する．なた， $\left(\mathrm{N}_{2}+10 \mathrm{ppm} \mathrm{SO} \mathrm{SO}_{2}\right)$ よりも $\left(\mathrm{N}_{2}+42.6 \mathrm{ppm}\right.$ $\mathrm{H}_{2} \mathrm{O}+10 \mathrm{ppm} \mathrm{SO}_{2}$ ) に扔いて質量増加が著しいことは，污染 物質 $\mathrm{SO}_{2}$ の影響が $\mathrm{H}_{2} \mathrm{O}$ の共存によって強調されることを示 唆する.

\section{4. 結言}

本研究では，質量変動を高感度にその場測定できる QCM
法を用いて， $\mathrm{Ni}$ 新生面の初期酸化挙動を調査した。すなわ ち, 水晶振動子上に $\mathrm{Au}$ あるいは $\mathrm{Ni}$ 新生面を生成させ， $\mathrm{N}_{2}$ および人工空気の導入・排出に伴う質量変動をその場測定す るとともに, $\mathrm{X}$ 線光電子分光を用いて生成相の結合エネル ギーを分析した，得られた結果は，以下のように要約できる.

(1) $\mathrm{Au}$ 新生面への $\mathrm{N}_{2}$ 導入では単層吸着が進行するが, この吸着層はその後の真空排気により完全に消失する. 一方, $\mathrm{Ni}$ 新生面では, ガス導入 $10 \mathrm{~s}$ 以内のごく初期に, 真空排気 などによっても脱着しない強い結合の単層吸着が生起する.

(2) 人工空気導入 ·排出に拈いて, $\mathrm{Au}$ 新生面では, $\mathrm{N}_{2}$ 導 入.排出の場合と同様の質量变動が観測される.これに対し, $\mathrm{Ni}$ 新生面では，ごく初期に化合物 $\mathrm{NiO}$ 層が生成すると推察 できる。また，この化合物層へのガス種の吸着も著しく， $1.01 \times 10^{5} \mathrm{~Pa}$ における質量増加は $\mathrm{N}_{2}$ 導入時の約 1.5 倍に達す る.

（3） $\mathrm{Ni}$ 新生面の初期酸化過程において, 混在する $\mathrm{H}_{2} \mathrm{O}$ は ガス導入のごく初期に生成する吸着層の質量を増大させる. 一方, $\mathrm{SO}_{2}$ はその後の質量増加速度を増大させる傾向を示す. XPS 分析では, S はガス導入のごく初期よりも, その後に 生成する吸着層に濃縮することが示される。

本研究は, 平成 9 年度〜平成11年度文部省科学研究費補 助金助成研究 (課題番号09875173)の一環として行われた. ここに付記し，感謝の意を表します。

文献

1) D. W. Rice, P. B. P. Phipps and R. Tremoureux: J. Electrochem. Soc. 127 (1980) 563-568.

2) D. Persson and C. Leygraf: J. Electrochem. Soc. 139(1992) $2243-249$.

3) S. Zakipour, J. Tidblad and C. Leygraf: J. Electrochem. Soc. 144(1997) 3513-3517.

4) K. Fujii, S. Kobayashi, M. Ito and N. Ohnaka: Corrosion Engineering 43(1994) 378-384.

5) S. Lee and R. W. Staehle: Corrosion Science 53(1997) 33-42.

6) S. Lee and R. W. Staehle: Materials and Corrosion 48(1997) 86-94.

7) T. Aastrup and C. Leygraf: J. Electrochem. Soc. 144(1997) 2986-2990.

8) A. W. Czanderna and R. Vasofsky: Progress in Surface Science 9 (1979) 45-75

9) M. Taguchi and T. Hirasawa: J. Surface Finishing Soc. Japan 48(1997) 1025-1031.

10) G. Sauerbrey: Z. Physik 155(1959) 206-222.

11) W. E. Swartz, Jr. and M. Youssefi: J. Electron Spectrosc. Relat. Phenom. 8(1976) 61-70.

12) N. Ikeo, Y. Iijima, N. Niimura, M. Sigematsu, T. Tazawa, S. Matsumoto, K. Kojima and Y. Nagasawa: Handbook of X-ray Photoelectron Spectroscopy, (JEOL, Tokyo, 1991) 71.

13) C. P. Li, A. Proctor and D. M. Hercules: Appl. Spectros. 38 (1984) 880-886.

14) A. N. Mansour and C. A. Melendres: Surface Science Spectra 3(1996) 247-254

15) D. Wagner: Practical Surface Analysis, Vol. 1, Auger and X-ray Photoelectron Spectroscopy, 2nd. Ed., Ed. by D. Briggs and M. P. Seah, (Wiley, New York, 1990) 608.

16) G. T. Tyuliev and K. L. Kostov: Phys. Rev. B 60(1999) 2900-2907.

17) M. Taguchi and M. Watanabe: Unpublished data.

18) C. D. Wagner and J. A. Tayler: J. Electron Spectros. Relat. Phenom. 20(1980) 83-93.

19) J. F. Moulder, W. F. Stickle, P. E. Sobol and K. D. Bomben: Handbook of X-ray Photoelectron Spectroscopy, (Parkin-Elmer Corporation, Minnesota, 1992) 61. 